\title{
The relationship between excess returns, firm size and earnings on the Johannesburg Stock Exchange
}

\author{
Michael J. Page* and Francis Palmer \\ Graduate School of Business, University of Cape Town, Private Bag Rondebosch 7700, Republic of South Africa
}

Received 19 January 1991; accepted 17 June 1991

\begin{abstract}
While considerable empirical work has been conducted in the United States concerning excess returns and the relationship of these returns to firm size and E/P ratio, thus far, there have been few similar empirical studies conducted using Johannesburg Stock Exchange (JSE) data. Evidence of firm size or E/P ratio effects has been ascribed by various authors to either model misspecification or market inefficiencies. In this article the evidence is examined for the South African market using 1370 company years of data over the period 1978 to 1988, and a significant eamings effect is found, but no size effect. In the analysis the problem of data bias is considered with particular emphasis on thin trading issues, and a methodology for future empirical work is described. Finally, it is suggested that the evidence can be better explained by market inefficiencies than model misspecification.
\end{abstract}

Terwyl beduidende empiriese werk in die Verenigde State van Amerika gedoen is ten opsigte van cormatige winste en die verband tussen maatskappy-grootte en prysverdiensteverhoudings, is daar tot nou we min soortgelyke empiriese studies gedoen om die data op die Johannesburgse Effektebeurs te verwerk. Bewyse van resultate van maatskappygrootte of prysverdiensteverhoudings is deur verskeie outeurs toegeskryf aan of modelwanspesifikasie of markondoeltreffendheid. In hierdie artikel word die aanduidings van die Suid-Afrikaanse mark ondersoek deur die data van 1370 maatskappyjare oor die tydperk 1978 tot 1988 te gebruik, en is 'n betekenisvolle verdienste- maar geen noemenswaardige grootte-effek gevind nie. In die ontleding word die probleem van data-onewewigtigheid oorweeg met spesifieke klem op min handelsaangeleenthede en 'n metodiek vir toekomstige empiriese werk word beskryf. Ten slotte word aangevoer dat die aanduidings beter verklaar kan word deur markondoeltreffendheid as deur modelwanspesifikasie.

*Author to whom any correspondence should be addressed.

\section{Introduction}

Over the last decade there has been intense debate in the United States concerning excess market returns and whether these returns are related to firm size and $E / P$ ratio. The existence of excess returns has prompted some researchers to suggest that either the CAPM is misspecified or that the market is inefficient (Reinganum, 1981a: 20; Banz, 1981; Basu, 1983). Other researchers are not convinced and suggest that excess returns have been found as a result of data biases (Roll, 1981: 882; Banz and Breen, 1986: 791). This article investigates whether there are size and eamings effects on the JSE.

A complicating factor for empirical research undertaken using JSE data is that many of the shares trade infrequently. The beta coefficient of thinly traded firms tends to be underestimated causing antificially inflated returns. Particular attention has been given to minimising the serial correlation effect, caused by thin trading, and other data biases. The methodology that has been used is described in detail in the third section.

The results of this article show that there is a significant E/P effect but no evidence of a firm size related effect. These results are presented in the fourth section. In the discussion the results are contrasted with the findings of other researchers. Finally, a summary of the findings is presented in the concluding section.

\section{Literature review}

The development of the CAPM model is based on a series of assumptions including that all investors are risk averse, prefer greater wealth to less wealth, have a common investment horizon and a homogeneous set of expectations (Fama
1968: 30). Furthermore, it is also assumed that there are equal borrowing and lending rates, no taxes or transactions costs, efficient markets and normally distributed retums on securities (Copeland and Weston, 1988: 331). Many of these assumptions are clearly questionable in the real world. Investors do not have common investment horizons or homogeneous expectations and markets are not frictionless. In practice, the distribution of returns on securities is positively skewed and cannot be adequately described by two parameters. The downside is limited to loss of the initial investment while the upside is unbounded. This asymmetry has been observed in both the United States (Blume, 1970) and South African capital markets (Klerck and du Toit, 1986).

Although many of the assumptions inherent in the CAPM formulation appear to be violated in the real world the CAPM is still the accepted financial theory which is used in capital budgeting, cost of capital and investment decisions. Consequently, the CAPM has been the subject of investigation by numerous researchers to determine whether it is valid in practice.

Blume and Friend (1973) performed an empirical test of the CAPM and concluded that the capital asset pricing theory did not provide an adequate explanation of the observed returns. They indicated that the returns on the bond and stock markets appear to be segmented and that more comprehensive theories need to be developed to explain the observed returns. Furthermore, they suggested that the best method to determine the trade-off between risk and return is to perform empirical analysis (1973: 32). They made no mention of the market efficiency as a possible cause for their conflicting results with the CAPM theory. 
In contrast to the findings of Blume and Friend, an empirical investigation was also conducted by Fama and Macbeth (1973) in which different conclusions were obtained; namely that their results were consistent with an efficient capital market and the CAPM's linear relationship between portolio risk and expected return. It was suggested that the level of efficiency implicit in this test was weakform since the ex-post returns are based on a time series of past returns.

Roll (1977), in criticising the empirical work of Blume and Friend, and Fama and Macbeth suggested that the CAPM cannot be verified empirically because of the dual nature of the hypothesis being tested. He contended that the theory could only be tested if the exact composition of the market portfolio was known. Furthermore he suggested that the use of a proxy for the market portfolio will influence the predicted beta value as beta is a relative measure of risk (1977: 132). Cook and Rozeff in support of the testability argument of Roll, suggested that the problem exists because the CAPM is inextricably linked to the principle of efficient markets. It is evident that an empirical test of the CAPM is fraught with difficulty. Not only is the joint hypothesis self referential but any test for consistent abnormal returns using the CAPM can be criticised because it can be argued that it is not the correct tool to use for the test (Copeland and Weston, 1988: 351).

With respect to the South African evidence, recent studies performed on the JSE indicate that the market might be semi-strong form efficient (Knight and Affleck-Graves, 1985: 159). In an earlier article Gilbertson and Roux also concluded that the JSE is efficient but did not report the level of efficiency (1978: 30 ). Contrary to the above findings however, Strebel claimed that, at best, only half the JSE can be considered consistent with the efficient market hypothesis (1978: 29). Nevertheless, he did suggest that market efficiency tests may be appropriate using the CAPM for well traded shares, even if, because of the non-random nature of the retums, they are somewhat questionable in thin trading conditions. Finally, Strebel also highlighted the problem of bias which is introduced when estimating beta values in thin trading conditions since betas are calculated using observed results based on 'stated' prices instead of 'true' prices.

In spite of the empirical difficulties mentioned above, the CAPM is widely accepted as the definitive relationship between risk and expected return. According to this theory no investor should be able to earn consistent retums in excess of the risk free rate plus a premium for bearing market wide, or non-diversifiable, risk. In practical terms, measurements of risk can only be made using observed security price histories. As new information becomes available the risk premium that is required by investors may change. Consequently, when the ex-post version of the CAPM is used some securities produce returns greater than the expected retum and others will perform worse than expected. For well diversified portfolios, assuming that the capital market is efficient, there should, on average, be no risk adjusted excess retums over reasonable periods of time.

Many studies have been conducted in the United States to determine whether investors can consistently earn excess retums. Much of this research has focused on trying to determine whether excess returns are related to certain factors with the most well known being firm size and E/P ratios. Furthermore, some researchers also suggest that excess returns are eamed during the month of January which may be related to the investors rationalising their stock holdings before the end of the United States tax year.

The research that is of interest in this article concerns the size and eamings effects. Although not conclusive, the research conducted on this subject in the United States tends to indicate that excess returns on the AMEX and NYSE exchanges are related to size and eamings effects. There has been intense debate to determine whether these findings indicate market inefficiency, misspecification of the CAPM, or whether they are merely the result of data bias. Furthermore, the size and earnings effects do not appear to be stationary with respect to time. This has also caused disagreement amongst researchers concerning the relationship of these excess retums to size and earnings effects.

In an initial study Reinganum showed that abnormal returns were obtained for the portfolios of small firms which on average were more than $20 \%$ higher than for portfolios of the larger firms (1981b: 52). Reinganum concluded that the single period CAPM model is misspecified and that the firm size and $E / P$ effects are related but that the size effect subsumes the E/P effect (1981a: 20).

Roll (1981) investigated the implications of serial correlation and noted that Reinganum's use of daily returns data seriously biases the estimates of the beta values downwards due to thin trading. He suggested that serial correlation could be the cause of the small firm effect found by Reinganum because these firms would display artificially high risk adjusted returns due to auto-correlation bias (1981: 882). In order to address this issue, in a second study Reinganum (1982) used Dimson's method for calculating beta values when shares are subject to infrequent trading. Dimson suggests the method provides a more "consistent estimate of beta ... by aggregating the slope coefficients ...' (1979: 204). Reinganum recognised that the re-evaluation of beta did help to explain a little of the small firm effect but maintained that even when the method was used the small firm portfolios still outperformed the large firm portfolios by at least $20 \%$ per year (1982: 35 ).

Banz (1981) suggested that the use of an equal weighted index is preferable to one that is value weighted because it reduces the problem of overestimation of high beta securities and underestimation of low beta securities. In addition, he also used monthly returns data which, as discussed above, reduces the errors associated with serial correlation (1981: 6-8). Banz concluded that; firstly, as indicated by Reinganum, smaller firms consistently outperformed the larger firms over the sample period, and secondly, this was likely to have resulted because of misspecification of the CAPM and not market inefficiency.

Basu adjusted Reinganum's methodology to better account for systematic risk. His findings support those of Reinganum (1981a; 1981b) and Banz (1981) with respect to the size effect. However, Basu did not concur with the results found by Reinganum concerning the E/P effect. Basu showed that on average the high $E / P$ ratio securities outperformed those of low E/P firms and that the E/P effect is 
not subsumed by the size effect but rather the reverse. In addition, he agreed with the conclusions of Banz concerning misspecification of the CAPM because the E/P effect does not appear to be related to informational effects (1983: 150).

In support of the conjecture of Roll, Blume and Stambaugh (1983) showed that the size effect anomaly is pronounced when using daily returns data and that returns based on closing prices are biased upwards due to the bidask spread. They found this effect to be more pronounced for the smaller firms. Blume and Stambaugh also showed that the magnitude of the size effect reported by Reinganum is halved when a buy and hold strategy is adopted and that nearly all of the excess returns occur in January.

Cook and Rozeff (1984) undertook an analysis of size and $E / P$ effects in order to try to resolve the conflicting conclusions reached by both Reinganum (1981a and 1981b) and Basu (1983) concerning the E/P effect. They concluded that the most important variable was the January excess return and cross dependence of the January effect with the $E / P$ and size effects. In contrast to Basu (1983) they found that the $E / P$ and size effects were independently significant (1984: 455).

Banz and Breen (1986) investigated the effect of ex-postselection bias and look-ahead bias on empirical relations between market return and firm size and earnings yield. Expost-selection bias occurs when the stock records only contain data from surviving companies. Look-ahead bias occurs when the accounting information is used for a data sample prior to that information being made public. They showed that both the ex-post-selection bias and the lookahead bias had an effect on the observed differences in results and specifically that low P/E portfolios had higher returns when subject to look-ahead bias (1986: 789). When the effect of look-ahead bias was removed they found that there was no relationship between $\mathrm{P} / \mathrm{E}$ and market return. They acknowledge that look-ahead bias can be effectively reduced by restricting the companies analysed to fiscal years ending in December with introduction of accounting data at the end of March (1986: 793).

Jaffe, Keim and Westerfield (1989) attempted to replicate some of the work undertaken by previous researchers by using a longer time sample extending from 1950 to 1986 and controlling for ex-post selection bias. The reason given for their analysis was that the results of previous researchers appeared to be inconclusive as

'(e)arlier evidence concerning the relation between stock returns and the effects of size and E/P is not clear-cut. Reinganum (1981a: 20) argues that size dominates E/P, while Basu (1983: 150) concludes that E/P dominates size. Cook and Rozeff (1984: 464) attach approximately equal significance to both factors. Banz and Breen (1986: 793) can find no separate E/P ratio effect' (1989:147).

Jaffe et al. investigated the relationship between size, E/P and January effects using monthly risk adjusted excess returns and the Seemingly Unrelated Regression (SUR) method to derive market model coefficients. This method has the advantage of calculating the beta values 'in sample' and circumventing the problem of error-in-variables due to cross-correlation (1989: 140). However, the method does assume that there is no serial correlation which, as shown by Roll (1981) and Reinganum (1982), causes an overestimation of anomalous returns especially for those firms which are thinly traded. When all months were considered they found significant size and E/P effects. When the month of January was investigated separately significant size and $E / P$ effects were still evident but for the remaining months only the E/P effect was significant (1989: 148).

\section{Methodology}

\section{Data sample}

The data was obtained from two sources. The Ivor Jones, Roy \& Company database was used to extract preliminary results announcement dates, amount of common stock in issue, and earnings per share at the preliminary announcement date. A second database maintained at the University of Cape Town, Graduate School of Business, was used to extract monthly share prices. A sample of 164 firms was used for which both share prices and at least three years of annual financial statement data were available. This data comprised 1370 company years of records over the period 1978 to 1988. The firms used in the analysis are listed in Appendix A.

As mentioned earlier, there is a potential of look-ahead bias when the accounting information is used for a data sample prior to that information being made public. Typically this may occur where earnings data is reported for a particular year end but this information is not available to the investor until some months later. Banz and Breen suggest that look-ahead bias has the effect of introducing the E/P effect (1986: 791). To minimise any potential lookahead bias effect the following procedure was adopted. Firstly, the market value of each firm was calculated using the number of ordinary shares in issue multiplied by the share price at the financial year-end date, and secondly, the $E / P$ ratio was calculated using the eamings per share and the share price at the preliminary announcement date.

Both databases used in the article do not contain firms which have ceased trading. Consequently, the data sample is subject to ex-post-selection bias. While Banz and Breen (1986: 791) suggest that it is the effect of biases in the data, both look-ahead and ex-post-selection which introduce apparent earnings anomalies, according to Jaffe, Keim and Westerfield

'Banz and Breen find that the estimation of the E/P effect is not very sensitive to the ex-post-selection bias but is quite sensitive to the look-ahead bias. Their analysis ... suggests that much of the measured $\mathrm{E} / \mathrm{P}$ effect is due to the failure to account for the lookahead bias' (1989: 137).

While it is recognised that ex-post-selection bias is a shortcoming of this article therefore, the more serious lookahead bias is accommodated.

\section{Ex-post version of the CAPM}

In order to perform empirical tests it is necessary to use obser red historical data rather than expectations. As such an ex-post model must be used. The ex-post version of the CAPM that can be used for an empirical study is given by equation (1). This version is appropriate if it is assumed that 
the retum on any asset is a fair game (Copeland and Weston, 1988: 212). Additionally since, in reality the risk free rate is not time invariant, if a multiperiod version of the expost model is used, where the risk free rate is assumed to be the return on a zero beta portfolio, then it is also necessary to impose the restriction that there are no transaction costs on short sales (Blume and Friend, 1973: 20). A final important difference between the ex-ante and ex-post models is that the empirical line must have a positive slope in the former model but no such limitation applies in the latter model.

$\mathbf{R}_{\mathbf{k}}-\mathbf{R}_{\mathbf{n}}=\alpha_{i}+\beta\left[R_{m t}-R_{\mathbf{n}}\right]+e_{i}$

where:

$\mathbf{R}_{\mathrm{k}} \quad=$ rate of return on security $\mathrm{i}$ in period $\mathrm{t}$;

$R_{m t}=$ rate of return on the market portfolio of assets in period $\mathrm{t}$;

$\mathbf{R}_{\mathrm{a}} \quad=$ risk free rate of retum in period $\mathrm{t}$;

$\beta_{i}=\operatorname{cov}\left(R_{h i} ; R_{m t}\right) / v a r\left(R_{m i}\right) ;$

$\alpha_{i} \quad=$ excess retum of security $i$; and,

$\mathbf{e}_{\mathrm{it}} \quad$ = security specific error term.

The CAPM implies that retums should lie along the security market line. In other words there should be no risk adjusted excess returns. In this case $\alpha_{i}=0$. The ex-post model, however, is expressed in terms of observed returns which vary stochastically (Fama, 1973: 611). In order to test for the persistence of excess returns, equation (1) must be used over many time periods to obtain the average actual excess return $\boldsymbol{\alpha}_{\mathbf{i}}$.

\section{Calculation of betas}

One of the features of the JSE is that a large proportion of securities are thinly traded. The price quoted for a share is based on the price at the last transaction. Consequently, shares which are traded infrequently will be positively autocorrelated and the estimated beta value will be underestimated (Stoll and Whaley, 1983: 64). It has been found in the United States that there is a positive relationship between frequency of share transactions and firm size. Therefore, it is the smaller firms that are likely to display auto-correlated share price time histories. As the beta values of these firms can potentially be underestimated the calculated risk adjusted retums are likely to be overestimated (Roll, 1981: 884).

Two methods were used to calculate beta values for each firm. The first method was the standard ordinary least squares (OLS) method that is normally used to derive values of beta. The second method employed the technique developed by Dimson (1979) and enhanced by Cohen, Hawawini, Maier, Schwartz and Whitcomb (1983) to overcome the problems of beta underestimation caused by serial correlation. Bradfield and Barr conducted a sensitivity study on the JSE and they showed that there is statistical significance for two lagged terms, the contemporaneous term and one leading term (1989: 171). Their procedure was therefore adopted for this article.

For the regressions a market index is used as a proxy for the market portfolio. An equal weighted or value weighted index can be used and this has an important influence on the beta estimates. Bradfield and Barr point out that a value weighted index such as the JSE-Actuaries Overall Index contains shares which are more likely to be actively traded, and consequently is itself likely to be affected by the thin trading phenomenon (1989: 172). The beta estimates using a value weighted index are likely to be larger than for an equally weighted index as this index also consists of less actively traded shares. Bradfield and Barr suggest that

'although the Equally Weighted Index itself does not escape the problem of thin trading, it does appear to yield more intuitively appealing estimates of beta (when used in conjunction with Cohen's estimator) than does the JSE-Actuaries Overall Index' (1989: 363).

An equally weighted index was therefore constructed and results using both beta computation methods are reported in the fourth section. The beta values were calculated for each month using the previous five years of data. A five year period for the regressions is widely used (Guerard, Bean and Stone, 1990: 363).

\section{Excess risk adjusted returns}

The returns were calculated by the percentage change in share price from one period to the next. Consistent with several prior studies, dividends were ignored, firstly because the bias introduced into the results have been shown to be minimal, and secondly, because of the portfolio grouping procedure which is discussed in the next section.

Risk adjusted excess returns were obtained for each security for each monthly time period using equation (2). The 90 day Banker's Acceptance rate was chosen as a proxy for the risk free rate.

$\alpha_{i t}=R_{i t}-R_{n}-\beta_{i}\left[R_{m t}-R_{n}\right]$

where:

$R_{\mathbf{i}} \quad=$ rate of retum on security $i$ in period $t ;$

$\mathbf{R}_{\mathrm{mt}} \quad=$ rate of retum on the market portfolio of assets in period t;

$\mathbf{R}_{\mathbf{n}} \quad=$ Banker's Acceptance rate in period $\mathbf{t}_{\mathbf{H}}$

$\beta_{i}=$ Cohen et al. or OLS beta estimated using the previous sixty months of data; and,

$\alpha_{i t}=$ excess return of security $i$ in period $t$.

\section{Portfolio construction}

For each firm in the data sample a market value and $E / P$ ratio were calculated for each year. There was an average of eight years data for each firm. Additionally, the average monthly excess returns for each firm and for each year were calculated. A number of ranking procedures are available for portfolio construction and these are described by Cook and Rozeff (1984: 452). The specific procedure adopted for this article is the within-groups method as it is widely used by researchers in this field (Jaffe, Keim and Westerfield, 1989: 137; Basu, 1983: 133). The advantage of this method is that each portfolio contains an approximately equal number of securities which reduces the degree of sampling error. The company year records in the data sample were first ranked according to the E/P ratio into 
nine groups. The first eight groups ranged from low to high positive $E / P$ ratios and the remaining group contained portfolios with negative $E / P$ ratios. Thereafter the $E / P$ based groups were each ranked according to firm size, based on market value, and then subdivided into eight further subgroups. A total of seventy-two portfolios were therefore constructed. The negative E/P ratio portfolios contained 10 securities each and the remaining sixty-four portfolios comprised 20 securities. Consequently, the 64 portfolios which contained firms with positive eamings were all well diversified, but, the portfolios that contained firms with negative earnings are more likely to exhibit greater unsystematic risk.

Each portfolio was equally weighted between individual securities. This method is widely used as it does not bias between smaller and larger firms. A value weighted portfolio displays weighting toward the langer firms with consequently less share price volatility and a lower portfolio beta value (Banz, 1981: 10).

\section{Test procedure for size and earnings effects}

As mentioned above, for each year the portfolio market value, E/P ratio, and average monthly excess returns were calculated. Equation (3) was used to test for the existence of size and eamings effects with all cross-sectional and serial excess returns pooled into a single two dimensional dataset for the portfolio construction. The lack of historical yearly data was the reason why this approach had to be adopted. The method therefore treated each year of company data independently and it was possible to have the same security represented more than once in a portfolio but for different periods in time. In order to ensure that the size data was consistent across time periods the market value of each firm was adjusted to reflect 1988 prices. The E/P ratio is nondimensional and therefore no correction was applied.

$\alpha_{\text {in }}=\alpha_{0}+\alpha_{1}(E / P)_{i t}+\alpha_{2}(L N M V)_{h}+\varepsilon_{i}$

where:

$(E / P)_{\text {it }} \quad=$ Average $E / P$ ratio of portfolio $i$ in period $t ;$ and,

$(\mathrm{LNMV})_{\text {it }}=$ Natural logarithm of the average market value of portfolio $i$ in period $t$.

The natural logarithm of firm size was used because Brown, Kleidon and Marsh (1983) have shown it to be linearly related to excess return, and the coefficients of equation (3) were obtained by regressing across all portfolios. The hypothesis tests for the existence of size and earnings effects are as follows:

Hypothesis la: $\mathrm{H}_{0}: \alpha_{0}=0 \quad \mathrm{H}_{1}: \alpha_{0} \neq 0$

Hypothesis 1b: $\mathrm{H}_{0}: \alpha_{1}=0 \quad \mathrm{H}_{1}: \alpha_{1} \neq 0$

Hypothesis 1c: $\mathrm{H}_{0}: \alpha_{2}=0 \quad \mathrm{H}_{1}: \alpha_{2} \neq 0$

If hypothesis la is rejected then excess returns are evident which are not explained by either size or earnings. The presence of excess retums which can be attributable to size and earnings effects will be determined from the outcome of hypothesis tests $1 \mathrm{~b}$ and 1c. If any of the estimates $\alpha_{0}, \alpha_{1}$, or $\alpha_{2}$ are statistically significant then either the JSE is inefficient or the CAPM is misspecified.

\section{Limitations of the test procedure}

As mentioned in the previous section, the method used required the pooling of serial and cross-sectional data due to limited available data for securities quoted on the JSE. The difficulty with this pooling technique concerns the loss in information by not using 'in sample' estimates of beta and not accounting for correlated residual errors.

Recently, the regression technique that is most commonly used in empirical analyses to circumvent the cross-sectional error-in-the-variables problem is the Seemingly Unrelated Regression (SUR) method (Jaffe, Keim and Westerfield, 1989; Banz and Breen, 1986; Brown et al., 1983). The SUR method produces, as part of the calculation procedure, in sample' estimates of the coefficients. Consequently this technique does not rely on beta estimates which are calculated a priori. Furthermore, the error-in-variables problem associated with cross-sectional correlation is no longer problematic as the variance-covariance matrix of errors is generated internally (Gibbons, 1982: 10). The limited serial data used in this article does not permit the use of this method. On a positive note though, Banz does suggest that grouping of data helps to minimise error-in-variables (1981: 5). The method that has been chosen for this article helps minimise the problems with serial correlation, but, crosssectional correlation of errors may still be a significant drawback. Finally, the SUR method may not, in any case, be ideally suited to the South African situation because of the thin share trading on the JSE.

It is apparent from the literature that each analysis technique does have limitations with respect to the errorsin-variables problem. The choice of analysis technique is therefore a trade-off between the errors associated with either serial or cross-sectional correlation.

\section{Results}

\section{Descriptive statistics}

Descriptive statistics are presented in Table 1. The presentation format of this data is similar to that used by Jaffe et al. in their investigation of size and earnings effects on the NYSE and AMEX for the period 1951 to 1986 (1989: 139). Average monthly excess retums, E/P ratios and market values are shown for each of the 72 portfolios. As stated in the methodology, these results are based on the period 1978 to 1988 using the within groups ranking procedure; ranking first by E/P ratio and then by market value. Excess risk adjusted returns have been calculated using both the Cohen et al. and the standard OLS methods.

The results shown in Panel A and Panel B of Table 1 indicate that most portfolios produced negative excess returns over the sample period. However, the firms with high E/P ratios have generally performed better than those with smaller E/P ratios. This trend is not entirely obvious from Table 1, therefore trend lines have been constructed for each firm size group and are presented in Figure 1. Ponfolio size groups one to seven display a positive trend slope as E/P ratio increases whereas the remaining trend line for the largest size group is marginally negative.

In contrast to the results found by Jaffe et al., the stocks with negative $E / P$ ratios in almost all cases performed 
Table 1 Average monthly excess returns, E/P ratios and market capitalization for 72 portfolios constructed using data from 164 firms over the period 1978 to 1988

\begin{tabular}{|c|c|c|c|c|c|c|c|c|c|}
\hline \multirow{4}{*}{ Size } & \multicolumn{9}{|c|}{ 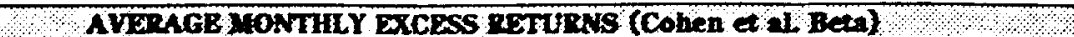 } \\
\hline & \multicolumn{9}{|c|}{ Average Monthly Rearns"a } \\
\hline & & & & Earnings & o Price & 40 & & & \\
\hline & $<0$ & Lowest & 2 & 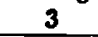 & 4 & 5 & 6 & 7 & Highe: \\
\hline Smallest & $\begin{array}{c}-2.17 \\
(0.02) \\
\langle 1.12\rangle\end{array}$ & $\begin{array}{l}-1.57 \\
(0.04) \\
<0.87>\end{array}$ & $\begin{array}{c}0.23 \\
(0.04) \\
<1.02>\end{array}$ & $\begin{array}{c}-1.25 \\
(0.03) \\
<0.90>\end{array}$ & $\begin{array}{c}-1.23 \\
(0.02) \\
\langle 0.71\rangle\end{array}$ & $\begin{array}{l}6 \\
\text { 3) } \\
7>\end{array}$ & $\begin{array}{c}0.39 \\
(0.04) \\
\langle 0.90\rangle\end{array}$ & $\begin{array}{c}0.32 \\
(0.05) \\
<1.39>\end{array}$ & $\begin{array}{l}0.24 \\
(0.02) \\
1.11>\end{array}$ \\
\hline 2 & $\begin{array}{l}-1.77 \\
(0.03) \\
<1.37\rangle\end{array}$ & $\begin{array}{c}0.40 \\
(0.06) \\
<0.62>\end{array}$ & $\begin{array}{c}0.75 \\
(0.02) \\
\langle 0.75\rangle\end{array}$ & $\begin{array}{c}3.72 \\
(0.14) \\
<1.13>\end{array}$ & $\begin{array}{l}-0.19 \\
(0.03) \\
<0.93>\end{array}$ & $\begin{array}{c}1.02 \\
(0.02) \\
<0.85\rangle\end{array}$ & $\begin{array}{l}-0.28 \\
(0.03) \\
<1.15>\end{array}$ & $\begin{array}{c}0.44 \\
(0.03) \\
<0.85>\end{array}$ & $\begin{array}{c}0.69 \\
(0.04) \\
<0.99>\end{array}$ \\
\hline 3 & $\begin{array}{c}0.48 \\
(0.07) \\
\langle 0.84>\end{array}$ & $\begin{array}{l}-1.45 \\
(0.04) \\
\langle 1.21\rangle\end{array}$ & $\begin{array}{l}-1.75 \\
(0.02) \\
\langle 1.11\rangle\end{array}$ & $\begin{array}{c}-0.36 \\
(0.02) \\
<1.02\rangle\end{array}$ & $\begin{array}{c}-0.62 \\
(0.04) \\
<0.84>\end{array}$ & & $\begin{array}{c}0.32 \\
(0.03) \\
<0.85>\end{array}$ & $\begin{array}{c}0.40 \\
(0.02) \\
\langle 0.94\rangle\end{array}$ & \\
\hline 4 & $\begin{array}{c}-0.85 \\
(0.09) \\
\langle 1.15\rangle\end{array}$ & $\begin{array}{c}-0.54 \\
(0.03) \\
\langle 0.94\rangle\end{array}$ & & $\begin{array}{c}0.76 \\
(0.06) \\
\langle 1.14\rangle\end{array}$ & $\begin{array}{c}0.11 \\
(0.03) \\
\langle 1.17\rangle\end{array}$ & & & & \\
\hline 5 & $\begin{array}{c}-2.52 \\
(0.04) \\
\langle 1.61\rangle\end{array}$ & $\begin{array}{c}-0.46 \\
(0.03) \\
\langle 0.98>\end{array}$ & $\begin{array}{c}-0.30 \\
(0.03) \\
<0.76>\end{array}$ & $\begin{array}{c}-0.14 \\
(0.02) \\
<0.89\rangle\end{array}$ & $\begin{array}{c}-0.96 \\
(0.03) \\
\langle 1.01\rangle\end{array}$ & $\begin{array}{c}0.99 \\
(0.05) \\
\langle 0.97>\end{array}$ & $\begin{array}{c}1.16 \\
(0.03) \\
\langle 0.90\rangle\end{array}$ & & \\
\hline 6 & $\begin{array}{r}-0.95 \\
(0.03) \\
\langle 1.55\rangle\end{array}$ & $\begin{array}{l}-0.31 \\
(0.03) \\
<0.99>\end{array}$ & $\begin{array}{l}-0.68 \\
(0.04) \\
\langle 1.06\rangle\end{array}$ & $\begin{array}{c}0.04 \\
(0.02) \\
\langle 1.01\rangle\end{array}$ & $\begin{array}{c}0.51 \\
(0.02) \\
\langle 1.00\rangle\end{array}$ & $\begin{array}{c}0.24 \\
(0.03) \\
<1.19\rangle\end{array}$ & $\begin{array}{c}0.75 \\
(0.02) \\
<1.12>\end{array}$ & $\begin{array}{c}-0.53 \\
(0.02) \\
<1.00\rangle\end{array}$ & $\begin{array}{c}-0.43 \\
(0.02) \\
\langle 1.18\rangle\end{array}$ \\
\hline 7 & $\begin{array}{l}-2.59 \\
(0.04) \\
<1.18>\end{array}$ & $\begin{array}{l}-1.52 \\
(0.03) \\
<1.07>\end{array}$ & $\begin{array}{r}-0.15 \\
(0.02) \\
<1.03\rangle\end{array}$ & $\begin{array}{c}0.18 \\
(0.02) \\
\langle 1.01\rangle\end{array}$ & $\begin{array}{c}0.75 \\
(0.03) \\
<0.83>\end{array}$ & $\begin{array}{c}-0.59 \\
(0.02) \\
\langle 0.97\rangle\end{array}$ & $\begin{array}{l}-0.25 \\
(0.02) \\
<1.01\rangle\end{array}$ & $\begin{array}{c}0.18 \\
(0.02) \\
<1.05>\end{array}$ & $\begin{array}{c}-0.17 \\
(0.03) \\
\langle 1.21\rangle\end{array}$ \\
\hline Largest & $\begin{array}{c}-2.3 \\
(0.03) \\
\langle 1.20\rangle\end{array}$ & $\begin{array}{c}3.77 \\
(0.18) \\
\langle 1.07\rangle\end{array}$ & $\begin{array}{l}-0.68 \\
(0.02) \\
\langle 1.05\rangle\end{array}$ & $\begin{array}{r}-0.49 \\
(0.01) \\
\langle 1.03\rangle\end{array}$ & $\begin{array}{c}-0.11 \\
(0.02) \\
\langle 0.94\rangle\end{array}$ & $\begin{array}{c}-0.24) \\
(0.02) \\
\langle 0.97>\end{array}$ & $\begin{array}{c}-0.09 \\
(0.02) \\
<0.90\rangle\end{array}$ & $\begin{array}{c}-0.31 \\
(0.03) \\
<0.81\rangle\end{array}$ & $\begin{array}{l}-0.37 \\
(0.03) \\
\langle 1.07\rangle\end{array}$ \\
\hline
\end{tabular}

\begin{tabular}{|c|c|c|c|c|c|c|c|c|c|}
\hline PALE & \multicolumn{9}{|c|}{ 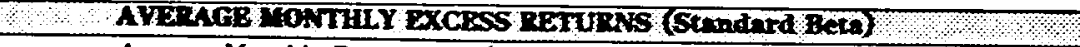 } \\
\hline \multirow{3}{*}{ Size } & \multicolumn{4}{|c|}{ Average Monthly Returns'-a } & \multirow{2}{*}{\multicolumn{2}{|c|}{$\frac{\text { (Standard Errors) })^{\sim b}}{0 \text { Price Ratio }}$}} & \multicolumn{2}{|c|}{ <Betas d } & \multirow[b]{3}{*}{ Highest } \\
\hline & \multirow[b]{2}{*}{$<0$} & \multirow[b]{2}{*}{ Lowest } & \multirow{2}{*}{\multicolumn{2}{|c|}{ Earnings to Price Ratio }} & & & \multirow[b]{2}{*}{ 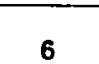 } & \multirow[b]{2}{*}{8} & \\
\hline & & & & 3 & 4 & 5 & & & \\
\hline Smaflest & $\begin{array}{c}-2.11 \\
(0.02)\end{array}$ & $\begin{array}{c}-1.44 \\
(0.03)\end{array}$ & $\begin{array}{r}-0.04 \\
(0.04)\end{array}$ & $\begin{array}{r}-1.24 \\
(0.03)\end{array}$ & $\begin{array}{r}-1.36 \\
(0.02)\end{array}$ & $\begin{array}{l}-1.82 \\
(0.03)\end{array}$ & 0.48 & 0.59 & 0.42 \\
\hline & $<0.92>$ & $<0.80>$ & $<0.96>$ & $\langle 0.8\rangle$ & $\langle 0.7 \mathrm{I}\rangle$ & $\langle 1.07\rangle$ & $\begin{array}{l}(0.04) \\
<0.89>\end{array}$ & $\begin{array}{l}(0.05) \\
<1.16>\end{array}$ & 2) \\
\hline 2 & $\begin{array}{r}-1.50 \\
(0.03)\end{array}$ & $\begin{array}{c}0.55 \\
(0.05)\end{array}$ & 0.82 & 3.78 & -0.17 & 0.88 & -0.49 & 0.55 & 0.87 \\
\hline & $<1$ & 10 & (0) & 3) & (0. & $(0.02)$ & $(0.03)$ & $(0.03)$ & $(0.03)$ \\
\hline 3 & 0.33 & $\begin{array}{c}<0.60> \\
-0.50\end{array}$ & $\begin{array}{l}<0.56> \\
-1.52\end{array}$ & $\begin{array}{l}<1.19> \\
-0.10\end{array}$ & $\begin{array}{l}<0.93> \\
-0.68\end{array}$ & $\begin{array}{c}<0.84> \\
-0.40\end{array}$ & $<1.15>$ & $<0.87>$ & \\
\hline & $(0.06)$ & $(0.04)$ & $(0.03)$ & $(0.02)$ & $(0.04)$ & $(0.02)$ & $(0.02)$ & $\begin{array}{c}0.20 \\
(0.02)\end{array}$ & $\begin{array}{c}-0.12 \\
(0.03)\end{array}$ \\
\hline & $0.69\rangle$ & $\langle 1.24\rangle$ & $<0.99>$ & $<1.02\rangle$ & $\langle 0.84\rangle$ & $\langle 0.86\rangle$ & $<0.85>$ & $<0.89\rangle$ & $\langle 1.09\rangle$ \\
\hline 4 & $\begin{array}{c}-0.92 \\
(0.09)\end{array}$ & $\begin{array}{r}-0.50 \\
(0.03)\end{array}$ & $\begin{array}{c}-0.23 \\
(0.03)\end{array}$ & $\begin{array}{c}0.50 \\
(0.06)\end{array}$ & & & -0.52 & -0.07 & -0.71 \\
\hline & $\langle 1.06\rangle$ & $<0.88>$ & $<1.23\rangle$ & $<1.19\rangle$ & $\langle 1.13\rangle$ & $<0.91>$ & $(0.03)$ & 0 & 3) \\
\hline 5 & -2.68 & -0.42 & -0.47 & -0.29 & -1.42 & 0.77 & 1.19 & -1.03 & $\begin{array}{c}<0.98> \\
-0.83\end{array}$ \\
\hline & (C) & $(0.03)$ & $(0.03)$ & $(0.03)$ & $(0.04)$ & $(0.05)$ & $(0.03)$ & $(0.03)$ & $(0.03)$ \\
\hline & $\langle 1.58\rangle$ & $<0.98>$ & $<0.88>$ & $\langle 1.12\rangle$ & $\langle 1.33\rangle$ & $\langle 1.13\rangle$ & $\langle 1.00\rangle$ & $\langle 1.04\rangle$ & $\langle 1.00\rangle$ \\
\hline 6 & -0.99 & -0.35 & -0.73 & 0.04 & 0.31 & 0.16 & 0.51 & & -0.46 \\
\hline & $(0.05)$ & $(0.03)$ & $(0.04)$ & $(0.02)$ & $(0.02)$ & $(0.02)$ & $(0.02)$ & $(0.02)$ & $(0.02)$ \\
\hline 7 & $\langle 1.98\rangle$ & $<1.09>$ & $\langle 1.07\rangle$ & $\langle 1.03\rangle$ & $<1.02\rangle$ & $\langle 1.16\rangle$ & $\langle 1.21\rangle$ & $\langle 1.01\rangle$ & $\langle 1.10\rangle$ \\
\hline 7 & $\begin{array}{c}-2.44 \\
(0.05)\end{array}$ & $\begin{array}{c}-1.41 \\
(0.03)\end{array}$ & $\begin{array}{r}-0.02 \\
(009)\end{array}$ & -0.09 & 0.58 & -0.69 & -0.40 & 0. & \\
\hline & $\langle 1.15\rangle$ & $<1.05\rangle$ & $<1.0$ & $(0.02)$ & $(0.02)$ & $(0.03)$ & $(0.02)$ & $(0.02)$ & $(0.03)$ \\
\hline Largest & -2.25 & 3.45 & -0.57 & $\left\langle\begin{array}{c}\langle 1.12\rangle \\
-0.41\end{array}\right.$ & $<0.93>$ & $\langle 1.08\rangle$ & $<1.10\rangle$ & $\langle 1.08\rangle$ & $\langle 1.17\rangle$ \\
\hline & $(0.03)$ & (0.17) & $(0.02)$ & $(0.01)$ & $(0.02)$ & $(0.02)$ & $(0.03)$ & $(0.03)$ & $\begin{array}{c}-0.63 \\
(0.03)\end{array}$ \\
\hline & & $-2-1$ & $<1.04$ & $\langle 1.00\rangle$ & $\langle 0.96\rangle$ & $\langle 1.02\rangle$ & $<0.90\rangle$ & $\langle 0.95\rangle$ & 1. \\
\hline
\end{tabular}

\begin{tabular}{|c|c|c|c|c|c|c|c|c|c|}
\hline \multirow[t]{3}{*}{$3,1 \times 18$} & \multicolumn{9}{|c|}{ 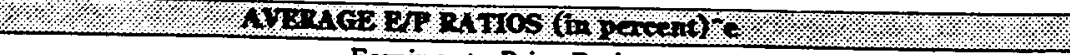 } \\
\hline & \multirow[b]{2}{*}{$<0$} & \multirow[b]{2}{*}{ Lowest } & \multicolumn{4}{|c|}{ Earnings to Price Ratio } & \multirow[b]{2}{*}{6} & \multirow[b]{2}{*}{7} & \multirow[b]{2}{*}{ Highest } \\
\hline & & & 2 & 3 & 4 & 5 & & & \\
\hline $\begin{array}{c}\text { Smallest } \\
2 \\
3 \\
4 \\
5 \\
6 \\
7 \\
\text { Largest }\end{array}$ & $\begin{array}{l}-64.01 \\
-58.28 \\
-54.99 \\
-35.44 \\
-28.99 \\
-62.23 \\
-44.15 \\
-12.65\end{array}$ & $\begin{array}{l}3.64 \\
4.42 \\
4.18 \\
3.85 \\
3.94 \\
4.38 \\
3.86 \\
5.04\end{array}$ & $\begin{array}{l}8.32 \\
8.07 \\
8.19 \\
8.22 \\
8.29 \\
8.14 \\
8.11 \\
8.35\end{array}$ & $\begin{array}{l}10.88 \\
10.66 \\
10.69 \\
10.65 \\
10.65 \\
10.80 \\
10.68 \\
10.69\end{array}$ & $\begin{array}{l}12.91 \\
13.15 \\
13.25 \\
13.30 \\
13.36 \\
12.87 \\
13.20 \\
12.75\end{array}$ & $\begin{array}{l}15.77 \\
15.71 \\
16.05 \\
15.65 \\
15.66 \\
15.64 \\
15.73 \\
15.34\end{array}$ & $\begin{array}{l}18.79 \\
18.65 \\
18.55 \\
19.07 \\
18.28 \\
18.67 \\
18.35 \\
18.60\end{array}$ & $\begin{array}{l}23.6 \\
22.78 \\
23.31 \\
22.70 \\
22.74 \\
23.40 \\
23.41 \\
22.39\end{array}$ & $\begin{array}{l}\mathbf{5} 1.74 \\
\mathbf{3 6 . 1 1} \\
\mathbf{3 3 . 3 8} \\
\mathbf{3 4 . 7 0} \\
\mathbf{3 2 . 6 7} \\
\mathbf{3 5 . 4 2} \\
\mathbf{3 3 . 8 8} \\
\mathbf{3 8 . 0 0}\end{array}$ \\
\hline
\end{tabular}


Table 1 (cont.)

\begin{tabular}{|c|c|c|c|c|c|c|c|c|c|}
\hline \multirow[t]{2}{*}{ RoNal D } & \multirow{2}{*}{\multicolumn{9}{|c|}{ 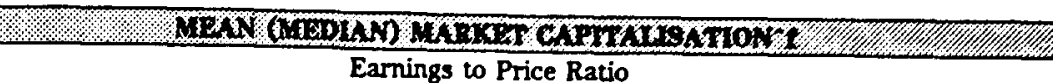 }} \\
\hline & & & & & & & & & \\
\hline Size & $\leq 0$ & Lowest & 2 & 3 & 4 & 5 & 6 & 7 & Highest \\
\hline Smallest & $\begin{array}{c}2 \\
(2)\end{array}$ & $\stackrel{5}{(5)}$ & $\begin{array}{c}13 \\
(14)\end{array}$ & $\begin{array}{c}21 \\
(25)\end{array}$ & (14) & $\begin{array}{l}16 \\
(21)\end{array}$ & $(3)$ & $\begin{array}{c}7 \\
(7)\end{array}$ & $\begin{array}{c}8 \\
(3)\end{array}$ \\
\hline 2 & (4) & $\begin{array}{c}12 \\
(13)\end{array}$ & $\begin{array}{c}49 \\
(51)\end{array}$ & $\begin{array}{c}60 \\
(57)\end{array}$ & $\begin{array}{c}40 \\
(37)\end{array}$ & $\begin{array}{l}35 \\
(37)\end{array}$ & $\begin{array}{l}15 \\
(14)\end{array}$ & $\begin{array}{c}17 \\
(17)\end{array}$ & $\begin{array}{c}8 \\
(7)\end{array}$ \\
\hline 3 & $\stackrel{9}{9}$ & $\begin{array}{l}35 \\
(\mathbf{4 1})\end{array}$ & $\begin{array}{l}100 \\
(102)\end{array}$ & $\begin{array}{c}107 \\
(107)\end{array}$ & $\begin{array}{c}74 \\
(72)\end{array}$ & $\begin{array}{l}63 \\
(54)\end{array}$ & $\begin{array}{l}27 \\
(27)\end{array}$ & $\begin{array}{c}29 \\
(30)\end{array}$ & (14) \\
\hline 4 & $\begin{array}{c}16 \\
(16)\end{array}$ & $\begin{array}{c}72 \\
(72)\end{array}$ & $\begin{array}{c}169 \\
(170)\end{array}$ & $\begin{array}{c}167 \\
(164)\end{array}$ & $\begin{array}{c}114 \\
(115)\end{array}$ & $\begin{array}{c}88 \\
(96)\end{array}$ & $\begin{array}{c}44 \\
(44)\end{array}$ & $\begin{array}{c}45 \\
(48)\end{array}$ & $\begin{array}{c}22 \\
(22)\end{array}$ \\
\hline 5 & $\begin{array}{c}26 \\
(26)\end{array}$ & $\begin{array}{c}123 \\
(120)\end{array}$ & $\begin{array}{c}263 \\
(269)\end{array}$ & $\begin{array}{c}258 \\
(256)\end{array}$ & $\begin{array}{c}192 \\
(189)\end{array}$ & $\begin{array}{c}151 \\
(163)\end{array}$ & $\begin{array}{c}65 \\
(62)\end{array}$ & $\begin{array}{c}68 \\
(70)\end{array}$ & $\begin{array}{c}38 \\
(37)\end{array}$ \\
\hline 6 & $\begin{array}{c}56 \\
(57)\end{array}$ & $\begin{array}{c}211 \\
(205)\end{array}$ & $\begin{array}{c}443 \\
(463)\end{array}$ & $\begin{array}{c}401 \\
(407)\end{array}$ & $\begin{array}{c}334 \\
(352)\end{array}$ & $\begin{array}{c}236 \\
(229)\end{array}$ & $\begin{array}{c}122 \\
(124)\end{array}$ & $\begin{array}{c}109 \\
\text { (111) }\end{array}$ & $\begin{array}{c}62 \\
(60)\end{array}$ \\
\hline 7 & $\begin{array}{c}118 \\
(125)\end{array}$ & $\begin{array}{c}418 \\
(378)\end{array}$ & $\begin{array}{c}854 \\
(843)\end{array}$ & $\begin{array}{c}996 \\
(933)\end{array}$ & $\begin{array}{c}645 \\
(587)\end{array}$ & $\begin{array}{c}460 \\
(444)\end{array}$ & $\begin{array}{c}276 \\
(274)\end{array}$ & $\begin{array}{c}232 \\
(239)\end{array}$ & $\begin{array}{c}98 \\
(94)\end{array}$ \\
\hline Largest & $\begin{array}{c}261 \\
(257)\end{array}$ & $\begin{array}{c}1702 \\
(1028)\end{array}$ & $\begin{array}{c}3298 \\
(2154)\end{array}$ & $\begin{array}{c}3219 \\
(2723)\end{array}$ & $\begin{array}{c}2900 \\
(2782)\end{array}$ & $\begin{array}{c}3543 \\
(2354)\end{array}$ & $\begin{array}{c}2856 \\
(1601)\end{array}$ & $\begin{array}{l}1827 \\
(722)\end{array}$ & $\begin{array}{c}487 \\
(313)\end{array}$ \\
\hline $\begin{array}{ll} & \text { Risk ad } \\
\text { b } & \text { Stander } \\
\text { c } & \text { Betas C } \\
\text { d } & \text { Betas C } \\
\text { E } & \text { EP rat } \\
\text { P } & \text { Market }\end{array}$ & $\begin{array}{l}\text { ulated us } \\
\text { calculated } \\
\text { pitalisatio }\end{array}$ & standard & $\begin{array}{l}\text { ent } \\
\text { ates } \\
\text { al. entim } \\
\text { method } \\
\text { dets and } \\
\text { inencial }\end{array}$ & nd & 18 of $\mathrm{C}$ & $\operatorname{ces}$ & & & \\
\hline
\end{tabular}

worse than the other portfolios within the same firm size grouping. Survivor bias would artificially improve the performance of the low E/P portfolios. Consequently, the results of this article are intuitively appealing because it appears that there is little evidence of survivor bias.

Average E/P ratios and market capitalizations of the firms in each of the portfolios are shown in Panels $C$ and D respectively. The results reported in Panel $\mathrm{C}$ show that the

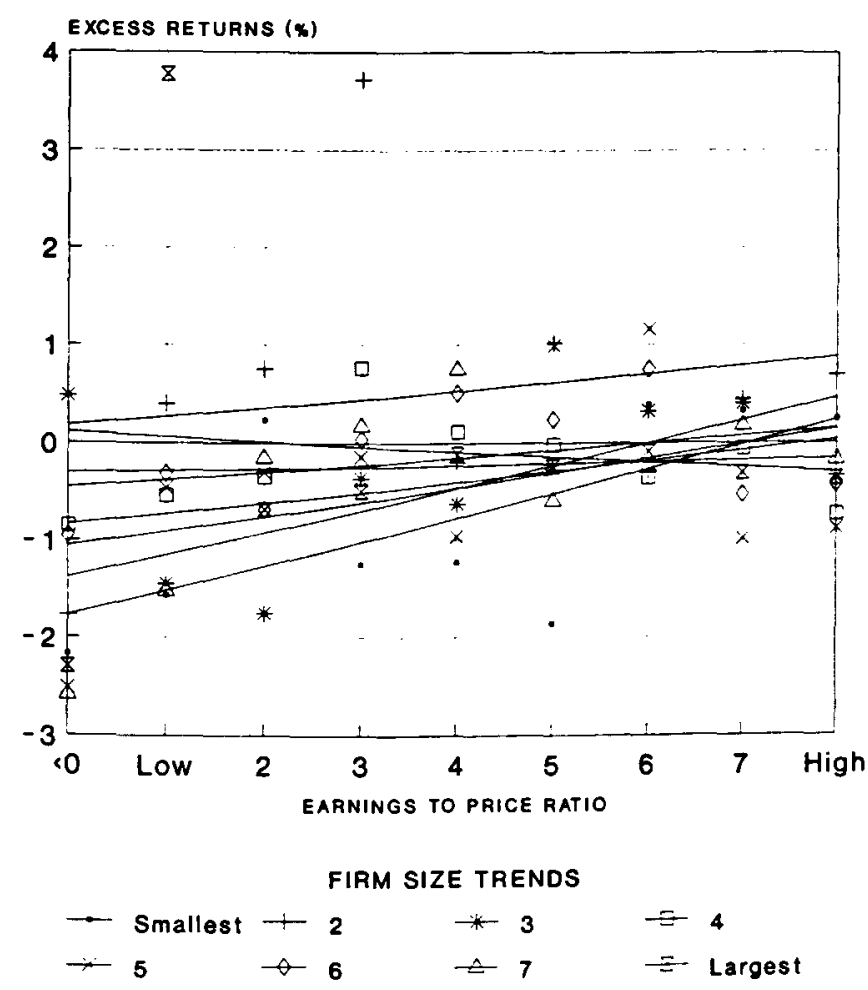

Figure 1 Average excess monthly returns versus E/P ratio graphs - showing trend lines
E/P ratios in each E/P group do not appear to be related to firm size. Inspection of the data in Panel D indicates that the maximum average firm size in each size group occurs at either $E / P$ ratio column 2 or 3 . This effect was also found by Jaffe et al., which they suggest may be the result of correlation between the size and E/P variables (1989: 140). They propose that the excess returns found in their study may therefore be explained by one effect, the market value effect As shown in the section on regression results this conclusion is not supported by the results of this anticle. While there may indeed be correlation between size and E/P effects the results indicate that the excess returns are related more to the eamings effect than the size effect.

\section{Effect of thin trading}

A comparison of the beta values using the calculation method proposed by Cohen et al. and the ordinary OLS method show that the beta coefficients calculated by both methods are not stationary. Greater volatility was found in the beta coefficients calculated using the Cohen et al. method. Panels A and B of Table 1 contrast the risk adjusted excess monthly returns using the two calculation methods. It is interesting to observe that the beta values using the Cohen et al. method are greater than those from the standard OLS method for the first four smallest size groups. For the remaining size groups this trend is reversed. The graph in Figure 2 shows this effect. This trend confirms the assumption that the thinly traded firms tend to be the smaller firms on the JSE. Roll also showed that this was true in the United States (1981: 884). The percentage differences were obtained by averaging the beta coefficients across all E/P groups. The trend shown in Figure 2 is to be expected because thinly traded securities will have underestimated betas, when the standard OLS method is used, and are likely to be those firms with small market capitalizations. 


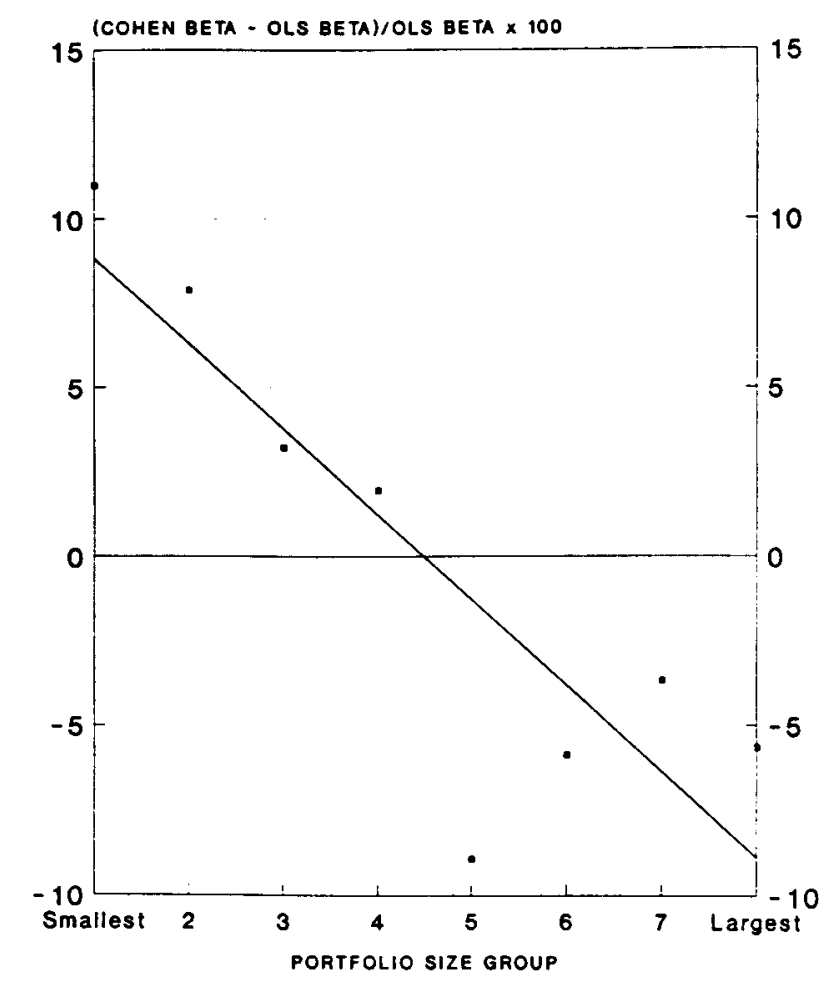

Note: The beta values are averaged

across all P/E groups

Figure 2 Graph of percentage difference between Cohen et al. and OLS betas as a function of portfolio size

The firms with the largest market values are generally traded the most frequently (in terms of the volume of share transactions). Consequently, the Cohen et al. method of beta estimation could be critised because it reduces the beta estimates for well traded shares. However, for a thinly traded exchange such as the JSE this method for estimating beta coefficients is desirable because it attempts to remove bias due to serial correlation.

\section{Regression results}

In order to determine whether the excess returns found in this article can be explained by either size or earnings ef- fects regression tests were performed to determine the significance of the coefficients in Equation (3).

The multiple regressions were performed using the portfolio average monthly excess returns as the dependent variable and the average E/P ratio and natural logarithm of the average market value as the independent variables. Tests were undertaken using both the excess returns based on the Cohen et al. and standard OLS beta calculation methods. The results of these regressions are reported in Table 2 and in both cases the regressions are found to be significant. The results show that the excess risk adjusted excess retums are explained principally by the earnings effect as the market value coefficient $\left(\alpha_{2}\right)$ is not at all significant and the intercept term $\left(\alpha_{0}\right)$ is only just significant at the $5 \%$ level for the Cohen et al. beta estimation approach. Consequently, it is not possible to conclusively reject hypotheses la and lc that $\alpha_{0}=\alpha_{2}=0$, but alternative hypothesis $1 b$ that $\alpha_{1} \neq 0$ can be accepted. Given the significance of $\alpha_{1}$ it would appear that either the JSE is inefficient or that the CAPM is misspecified. It is more likely that the JSE is inefficient however as this view is supported by the low trading volume of a large number of securities and the results of efficiency studies conducted by other researchers (Strebel, 1978; Knight and AffleckGraves, 1985).

Finally, it can also be observed from Table 2 that the choice of computation method to derive the excess returns does not affect the conclusion related to the eamings effect.

\section{Discussion}

This article has shown that excess returns on the JSE were only related to the earnings effect over the period 1978 to 1988. There was no size effect evident in the data. This result does not agree with the findings of De Villiers et al. (1986) who suggested that there is a size effect displayed on the JSE. Contrary to size effects found in the United States, De Villiers et al. found that, over the period 1973 to 1982, firms with large capitalizations outperformed smaller firms on a risk adjusted basis. They suggested that conditions peculiar to South Africa may explain this phenomenon, such as the inability of most institutions to invest abroad, or the presence of a few large companies that have

Table 2 Results of multiple regressions of excess return against E/P ratio and logarithm of firm size

\begin{tabular}{|c|c|c|c|c|c|}
\hline \multicolumn{6}{|c|}{ Regression results - extimntes of size and eamings coefficient } \\
\hline $\begin{array}{l}\text { Beta calculation } \\
\text { melhod }\end{array}$ & $\begin{array}{l}\text { R-square } \\
\text { (adjusted) }\end{array}$ & F-statistic & $\begin{array}{l}\text { Intercept } \\
\text { ocefficient }\end{array}$ & $\begin{array}{c}\text { E/P } \\
\text { coefficient }\end{array}$ & $\begin{array}{c}\text { Market value } \\
\text { coefficient }\end{array}$ \\
\hline Cohen et al. & 0,113166 & 5,53005 & - & - & - \\
\hline Coefficients & - & - & $-0,006748$ & 0,016584 & 0,000592 \\
\hline t atatistic & - & - & 2,095 & 3,019 & 0,874 \\
\hline Standard OLS & 0,103875 & 5,11503 & - & - & - \\
\hline Coefficients & - & - & $-0,005414$ & 0,016370 & 0,000253 \\
\hline I stutistic & - & - & $-1,730$ & 3,067 & 0,384 \\
\hline
\end{tabular}

Significant sutistics : $F$ [dof(num) $=2 ;$ dof(den $)=691=3,1330(4,9426)$

5\% level/(1\% level): $t[$ dof $=69]=1,9954(2,6494)$ 
controlling interests in a major number of the firms on the JSE (1986: 195).

The results of this article are in agreement with those of Basu who found that the securities of high E/P firms outperformed those with low E/P ratios, and, furthermore, that the earnings effect is dominant and subsumes the size effect. The absence of a size effect found in this article suggests that the JSE may be little different from the United States markets. This resulh, therefore, does question the validity of the conclusions reached by De Villiers et al. concerning the reasons why the performance of the South African differs from its counterpart markets overseas.

An interesting feature of the analysis is that the results are unaffected by the choice of beta regression methods. Roll suggested that serial correlation was the cause of the small firm effect (1981: 882). When Reinganum repeated his analysis of security performance over the sample period 1962 to 1975 using the Dimson method for estimating betas (1979) he found that the small firm effect was still evident and largely unaffected (Reinganum, 1981). The results of this article therefore agree with the conclusions of Reinganum because the portfolio excess retums using the Cohen et al. beta calculation method were essentially identical to those using the standard OLS computation method. While, initially this result may appear surprising because the JSE contains a greater proportion of thinly traded securities than exhibited on the American stock exchanges, the most important issue seems to be the choice of index for the beta calculations. Bradfield and Barr demonstrated that the beta estimates are significantly different when an equal weighted or value weighted index is used (1989: 171). This was also observed by Banz who noted overestimation of high beta securities and vice versa (1981: 8).

This conclusion has important implications concerning the methodology that ought to be adopted in future empirical studies since the main problems appear to relate to data bias. It has been suggested that serial, cross-sectional correlations and other bias effects are the cause of researchers' reporting anomalous returns and therefore the choice of analysis technique is especially important. A recommended approach for future empirical work on the JSE is given in the concluding section.

The earnings effect that has been found in this article is significant, and high E/P ratio firms appear to outperform the low E/P ratio firms. The increase in return that could be expected when an investment portfolio is reconstructed to consist of high E/P firms instead of low E/P firms can be approximated by the following procedure. The difference between the average $E / P$ ratio of the high and low E/P portfolios from Panel $C$ of Table 1 is $0,3699-0,0416=$ 0,3283 . The coefficient of the E/P term $\left(\alpha_{1}\right)$ from Table 2 is 0,0165 and consequently the increase in return is 0,0165 $x 0,3283=0,0054$ which is $0,54 \%$ per month or $6,5 \%$ per annum. Jaffe et al. performed this calculation and they determined that an increase of $3,2 \%$ per annum could be obtained by transferring stock holdings to high $E / P$ securities on the NYSE and AMEX (1989: 143).

The question conceming the JSE is whether the E/P effect found in this article is the result of market inefficiency or a misspecification of the CAPM. Various factors would suggest that the $E / P$ effect is the result of market in- efficiency and not a misspecification of the CAPM. Firstly, the JSE is thinly traded. Secondly, De Villiers et al. (1986) concluded that a size anomaly existed which was not found in the present article. This indicates that anomalous return effects may not be stationary which suggests that they are due to market inefficiencies. Thirdly, the sample period investigated in this article covers only ten years which is probably not long enough to conclude that there is a misspecification of the CAPM.

If it is accepted that the JSE is inefficient, then the fact that increased excess retums can be eamed by holding high E/P securities on the JSE than the American exchanges indicates that the JSE is less efficient than the NYSE or AMEX.

\section{Conclusions}

The results of this article indicate an E/P effect on the JSE for the period 1978 to 1988 . During this period investors could have earned $6,5 \%$ more per annum by holding high rather than low E/P securities. Basu (1983) and Jaffe et al. (1989) also found significant $E / P$ effects on the United States markets. The excess retums reported by Jaffe et al. are half those found in this article. This result indicates firstly that the JSE is less efficient than the NYSE or AMEX and, secondly, that the JSE does have similar excess returns characteristics to the United States markets. The results of the article are contrary to the findings of De Villiers et al. (1986) as no size effect was evident on the JSE over the sample period.

No advantage was found in using the sophisticated regression techniques proposed by Dimson (1979) or Cohen et al. (1983) to correct for auto-correlated share returns. It is suggested that it is more important to use an equal weighted market index as a proxy for the market portfolio to overcome the effects of thin trading. Additionally, since the SUR method uses 'in sample' estimates of beta, the Dimson or Cohen et al. beta calculation techniques cannot be used with the method. In order to exploit the SUR approach to overcome the problem of errors-in-variables associated with cross-sectional correlation it is therefore recommended that the method is used in combination with an equal weighted index to minimise the effects of serial correlation as well. This approach is recommended for any future empirical analysis which investigates anomolous share price behaviour.

\section{References}

Banz, R.W. 1981. The relationship between return and market value of common stocks. J. Fin. Econ., Vol. 9, 3-18.

Banz, R.W. \& Breen, W.J. 1986. Sample-dependent results using accounting and market data: Some evidence. J. Fin., Vol. 51, $779-793$.

Basu, S. 1983. The relationship between eaming's yield, market value and retum for NYSE common stocks. J. Fin. Econ., Vol. 12, 129-156.

Blume, M.E. 1970. Portfolio theory: A step lowand its practical application. J. Bus., Vol. 43, April, 152-173.

Blume, M.E. \& Friend, 1. 1973. A new look at the capital asset pricing model. J. Fin., March, 19-34. 
Blume, M.E. \& Stambaugh, R.F. 1983. Biases in computed returns - an application to the size effect. J. Fin. Econ., Vol. 12. 387-403.

Bradfield, D.J. \& Barr, G.D.I. 1989. Risk estimation in the thinly traded JSE environment. S. Afr. J. Bus. Manage., Vol. 20, 169-173.

Brown, P., Kleidon, A.W. \& Marsh, T.A. 1983. New evidence on the nature of size related anomalies in stock prices. J. Fin. Econ., Vol. 12, 33-56.

Cohen, KJ., Hawawini, G.A., Maier, S.F., Schwartz, R.A. \& Whitcomb, D.K. 1983. Friction in the trading process and the estimation of systematic risk. J. Fin. Econ., Vol. 12, 263-278.

Cook, T.J. \& Rozeff, S.R. 1984. Size and earnings/price ratio anomalies: One effect or two? J. Fin. and Quant. Anal., Vol. 19. No. 4, December, 449-466.

Copeland, T.E. \& Weston, J.F. 1988. Financial theory and corporale policy. Menlo Park, Califomia: 3rd Edition. Addison-Wesley, 946p.

De Villiers, P.G., Lowings, A J., Pettit, T.N. \& Affleck-Graves, J. 1986. An investigation into the small firm effect on the Johannesburg Stock Exchange. S. Afr. J. Bus. Manage., Vol. 17, No. 4, 191-195.

Dimson, E. 1979. Risk measurement when shares are subject to infrequent trading. J. Fin. Econ., Vol 7, 197-226.

Fama, E.F. 1968. Risk, return, and equilibrium: Some clarifying comments. J. Fin., March, 29-40.

Fama, E.F. \& Macbeth, J.D. 1973. Risk, return, and equilibrium: Empirical tests. J. Pol. Econ., May-June, 607-636.

Gibbons, M.R. 1982. Multivariate tests of financial models. J. Fin. Econ., Vol. 10, 3-27.

Gilbertson, B.P. \& Roux, FJ.P. 1978. Some further comments on the Johannesburg Stock Exchange as an efficient market. The Investment Analysts Journal, April, 21-31.

Guerard, J.B., Bean, S.A. \& Stone, B.K. 1990. Goal setting for effective corporate planning. Management Science, Vol. 31/2, No. 3, March, 359-367.

Jaffe, J., Keim, D.B. \& Westerfield, R. 1989. Earnings yields, market values, and stock returns. J. Fin., Vol. 54, 135-148.

WKlerck, W.G. \& Du Toit, G.S. 1986. An investigation into the return distributions of ordinary industrial shares on the J.S.E. The Investments Analysts Journal, May, 19-21.

Knight, R.F. \& Affleck-Graves, J.F. 1985. An empirical evaluation of the effectiveness of South African investment analysts. S. Afr. J. Bus. Manage., Vol. 16, 157-160.

Reinganum, M.R. 1981a. Misspecification of capital asset pricing - empirical anomalies based on earnings' yields and market values. J. Fin. Econ., Vol. 9, 19-46.

Reinganum, M.R. 1981b. Abnormal returns in small firm portfolios. Financial Analysts Journal, March-April, 52-56.

Reinganum, M.R. 1982. A direct test of Roll's conjecture on the small firm size effect. J. Fin., Vol. 37, 27-35.

Roll, R. 1977. A critique of the asset pricing theory's tests. J. Fin. Econ., March, 129-176.

Roll, R. 1981. A possible explanation of the small firm effect. $J$. Fin., Vol. 34, No. 4, September, 879-888.

Stoll, H.R. \& Whaley, R.E. 1983. Transaction costs and the small firm effect. J. Fin. Econ., Vol. 12, 57-79.

Strebel, P.J. 1978. Thin trading, market efficiency tests and the Johannesburg Stock Exchange: A rejoinder. The Investment Analysts Journal, August, 29-30.
Appondlx A: List of companies used in the article

List of companies used in the analysis

\begin{tabular}{|c|c|}
\hline Abercom Group & Aberdale Cables Africa \\
\hline Adcock-Ingram & Adonis Knitwear Holdings \\
\hline AECI & African Cables \\
\hline African Oxygen & Alex Lipworth \\
\hline Allied Electronics Corporation & Allied Tectnologies \\
\hline Amalgamated Retail & Anglo American Coal Corporation \\
\hline Anglo American Industrial Corp. & Anglo American Investment Truat \\
\hline Anglo Transval Colleries & Argus Holdings \\
\hline Associnted Engineering & Barlow Rand \\
\hline Beares & Bolton Industrial Holdings \\
\hline Bonuskor & Boymans \\
\hline Bradlows Stores & Broadacres Investments \\
\hline BTR Dunlop & Buffalo Corporation \\
\hline Burlington Industries & C G Smith Foods \\
\hline C G Smith & Cadbury Schweppes (SA) \\
\hline Carlion Paper Corporation & Caxton \\
\hline Cementation Company (Africa) & Chemical Services \\
\hline Chubb Holdings & Claude Neon \\
\hline Clicks Stores & CNA Gallo \\
\hline Concor & Crookes Brothers \\
\hline CTP Holdings & Cullinan Holdings \\
\hline Currie Motors (1946) & De Beers Consolidated \\
\hline Dekso & Delswa \\
\hline Delu Electrical Industries & Dorbyl \\
\hline Edgars Stores & Edward L Bateman \\
\hline Ellerine Holdings & Ensign Clothing \\
\hline Eurcka Industrial & Farm-AG \\
\hline Federale Volksbelegging & Fedfood \\
\hline Foschini & Frasers \\
\hline Frencorp & FSI Corporation \\
\hline Garlick Consolidated & General Optical Company \\
\hline Gentyre Industries & Globe Engineering Works \\
\hline Gold Fields Cole & Gresham Industries \\
\hline Grinaker Holdings & Group Five \\
\hline Gubb \& Inggs & Gypsum Industries \\
\hline Haggic & Hiveld Stcel \& Vanadium \\
\hline Hunt Leuchars \& Hepburn & H\&J Supreme Cables \& \\
\hline Holdings & Electronics \\
\hline Imperial Cold Storage & Industrial \& Commercial Holdings \\
\hline Interboard & Irvin \& Johnson \\
\hline Jabula Foods & KWV Investments \\
\hline Kanhym Investments & Kohler \\
\hline Landlock & LTA \\
\hline Lucem Holdings & Macphail Holdings \\
\hline Malbak & Malhold \\
\hline Masonite (Africa) & Mathieson \& Ashley Holdings \\
\hline McCarthy Group & Messina \\
\hline Metair Investments & Metal Box (SA) \\
\hline Metal Closures Group & Metje \& Ziegler \\
\hline Metkor Group & Montays \\
\hline Mooi Rjver Textiles & Murray \& Roberts Holdings \\
\hline M\&S Spizz Footwear Holdings & Nampak \\
\hline Natbolt Group & National Trading Company \\
\hline Nictus Beperk & Ninian \& Lester Holdings \\
\hline Northem Engincering Industries & OK Bazaars (1929) \\
\hline Oceana Fishing Group & Ois Elevator Company \\
\hline Pepkor & Picardi Appliances \\
\hline Picardi Beleggings & Picardi Holdings \\
\hline
\end{tabular}


Plate Glass Industries

Premier Group Hoddings

Press Supplies Holdings

Rembrandt Group

Reunert

Robor Industrial Holdings

SA Bias Holdings

$S$ M Goldruein

SAM Stecle Holdings

SASOL

Sentrachem

South Allantic Corporation

Steelmetals
Power Tochnologies

President Catering

Pretoris Porlend Cemene

Rentmeester Beleggings Bepert

Rex Trueform Clothing

Romatex

SA Breweries

SWA Fishing Industries

Seppi

Seardel Investment Corporation

Sinclair Holdings

Southem Sun Hotel Holdings

Stems Diamond Organieation
Suncrush

Tedelex

Times Modia

Towles Edgar Jacobs

Trums Natal Coal Corporation

Trencor

Unie Wyn Bepert

Utico Holdings

Verceniging Refineries

W A Invesument Corporation

Writbent Colliery

World Furniture Group
T W Bocten \& Compary

Yort Timber Organienion

Tongan-Huleat Group

Toyou SA

Trek-Belesgings Bepeat

Turf Holdings:

Unihold

Veka

Vierformein Colliery

Wallons Surionery

Wooluru 